\title{
A robust allegation of von Hippel-Lindau (VHL) associated haemangioblastoma in the central nervous system (CNS): A case report
}

\author{
Muhammad Yunus Amran*, Hasmawaty Basir, Andi Kurnia Bintang, Muhammad Akbar \\ Hasanuddin University Teaching Hospital, Department of Neurology, Faculty of Medicine, Hasanuddin University, Makassar, South \\ Sulawesi, Indonesia
}

\section{Email address:}

yunus_amran98@yahoo.com (M. Y. Amran), hasmawatibasir@yahoo.com (H. Basir), a.kurnia_b@yahoo.co.id (A. K. Bintang), akbar80fkuh@yahoo.com (M. Akbar)

To cite this article:

Muhammad Yunus Amran, Hasmawaty Basir, Andi Kurnia Bintang, Muhammad Akbar. A Robust Allegation of Von Hippel-Lindau (VHL) Associated Hemangioblastoma in the Central Nervous System (CNS): A Case Report. International Journal of Medical Imaging.

Vol. 2, No. 1, 2014, pp. 1-4. doi: 10.11648/j.ijmi.20140201.11

\begin{abstract}
Haemangioblastoma, a benign vascular tumor derived from the capillary of endothelial cells, is an inherited disorder due to an autosomal dominant trait. The prevalence rates accounted for $1 \%$ to $2.5 \%$ of all intracranial tumors and $2 \%$ to $3 \%$ of all intramedullary spinal cord tumors. We report the infrequent case of a robust allegation of von Hippel-Lindau (VHL) associated haemangioblastoma in the central nervous system of a man. A 20 years old male presented to the hospital with the chief complaint of progressive chronic cephalgia three months prior to hospitalization. He complained also of blurred vision on neurologic examination; there is papilla edema with suspicion of retinal edema. Radiological examination result suggested a cerebellar haemangioblastoma dextra with noncommunicating hydrocephalus. After the first operation (installation of VP shunting) and subsequent operation (excision of the tumor), the pathological anatomy results revealed a cavernous angioma.
\end{abstract}

Keywords: Haemangioblastoma, CNS, CT-Scan, Von Hippel-Lindau Diseases

\section{Introduction}

Haemangioblastoma, a benign vascular tumor derived from the capillary of endothelial cells [1,2.3], is an inherited disorder an autosomal dominant trait [2]. This tumor, located in the cerebellum, was reported for the first time by Arvid Lindau, known as Lindau's tumor [4], whereas when it occurred in the retina known as the von Hippel's tumor reported by von Hippel E [5]. This tumor was often associated with familial tumor of von Hippel-Lindau (VHL) syndrome which is found with cysts of the liver, pancreas and kidneys, nevi on the skin, kidney tumor, epididymis, and the adrenal [3]. Haemangioblastoma, occurs in all ages, but more on the young age and middle adult group (more than $80 \%$ ) which between the ages of 15-50 years with an average age of 33 years. The prevalence rates accounted for $1 \%$ to $2.5 \%$ of all intracranial tumors and $2 \%$ to $3 \%$ of all intramedullary spinal cord tumors. Haemangioblastoma is most commonly located in the posterior fossa with an estimated $10 \%$ of all tumors in the posterior fossa [2, 4]. Haemangioblastoma most often located on cerebellar paramedian area. In addition, it can also be located in the spinal cord for $2-3 \%$ of all tumors intramedullary. Here, we reported an infrequent case of a 20-year old man who admitted to the hospital with the final diagnose is cerebellum haemangioblastoma dextra and strongly suspected with von Hippel-Lindau disease.

\section{Case Report}

A 20 years old male was admitted to the hospital with the chief complaint of chronic progressive cephalgia, which experiencing for three months prior to his hospital admission. The complaint continuously occurred every day, and it perceived in all parts of his head and one month prior to the hospital became more severe, especially in the morning. He also vomited when he felt the cephalgia became heavier. The patient also complained of his blurred vision, which started about two weeks after the chief complaint arose. Together with his blurred vision, he also 
noticed that he was walking like a drunkard, and he felt dizzy every time he changed his body position and the pain never diminished. There was no history of head trauma, fever, cramps and weakness on one side of his body. The patient denied about a history of hypertension and similar illness in his family. The patient had no problems with either urination or defecation. On physical examination, his blood pressure was $170 / 120 \mathrm{mmHg}$; breathing 24 times/min with thoracoabdominal type; heart pulsation 80 beats $/ \mathrm{min}$ regular and temperature was $36.5^{\circ} \mathrm{C}$. Based on neurologic physical examination, we found bilateral optic disc cranial nerves edema (with suspected retinal edema) from the horizontal nystagmus to the right; no motor weakness and sensory disturbance. There was no disturbance of the autonomic nervous function. There was a disturbance of coordination tests; positive Romberg test, dysmetria for the finger-nose test, and dysdiadochokinesia. Routine and blood chemistry analyses revealed the following results: Hemoglobin ( $\mathrm{Hb}) 16.4 \mathrm{~g} / \mathrm{dl}$; white blood cell (WBC) $10.9 \times 10^{3} / \mathrm{mm}^{3}$; hematocrit (Hct) $47.6 \%$; platelet (PLT) $344.000 / \mathrm{mm}^{3}$; erythrocytes $5.46 \times 10^{6} / \mathrm{mm}^{3}$; random blood sugar (RBS) $157 \mathrm{mg} / \mathrm{dl}$; urea $18.43 \mathrm{mg} / \mathrm{dl}$; creatinine $1.04 \mathrm{mg} / \mathrm{dl}$; SGOT $15.1 \mathrm{mg} / \mathrm{dl}$ and SGPT 19 $\mathrm{mg} / \mathrm{dl}$. Axial head CT scans of both non-contrast and contrast to the administration of intravenous gadolinium (Gd-DOTA) were performed. From CT-scan without contrast showed a hypo-dense mass in the right posterior fossa pressing the fourth ventricle to the left and causing dilatation of the lateral and third ventricles.

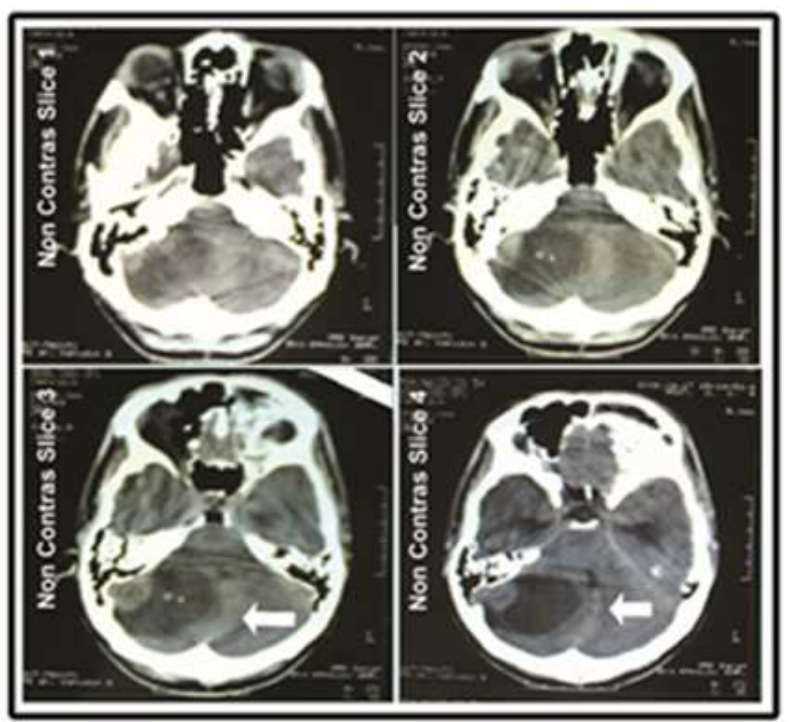

Figure 1. An axial head CT-scan without contrast appeared hypo-dense mass (16.5 to $17.7 \mathrm{HU}$ ) in the right posterior fossa pressing the fourth ventricle to the left and dilatation of the lateral and third ventricles. Midline shift to the left (white arrows). Paranasal sinuses and mastoid air cell within normal limit and bones were intact.

This result suggested a mass in the posterior fossa with non-communicating hydrocephalus (Figure 1) and CT-scan of the head with contrast showed a cystic mass on the wall with a solid component (white arrows) in the right posterior fossa (with the intensity range from 64.0 to $74.0 \mathrm{HU}$ ). Solid component became hyper-dense after contrast administration. These findings suggested a cerebellar haemangioblastoma dextra with non-communicating hydrocephalus (Figure 2). The patient underwent ventriculoperitoneal (VP) shunting to relieve the increase of intracranial pressure inside the skull due to the mass effect from the tumor in the fourth ventricle. Subsequently, 5-days after the VP shunting operation, a tumor excision surgery was done, and the tumor was successfully removed. The histopathology result: macroscopically visible network tattered soft off-white solid $1 \mathrm{cc}$; microscopically revealed tumor tissue with vascular proliferation, containing erythrocyte-coated endothelial cells with the diagnosis of cavernous angioma (Figure 3). The patient's condition improved and has not experienced cephalgia anymore but still felt dizzy and impaired coordination was still occurring.

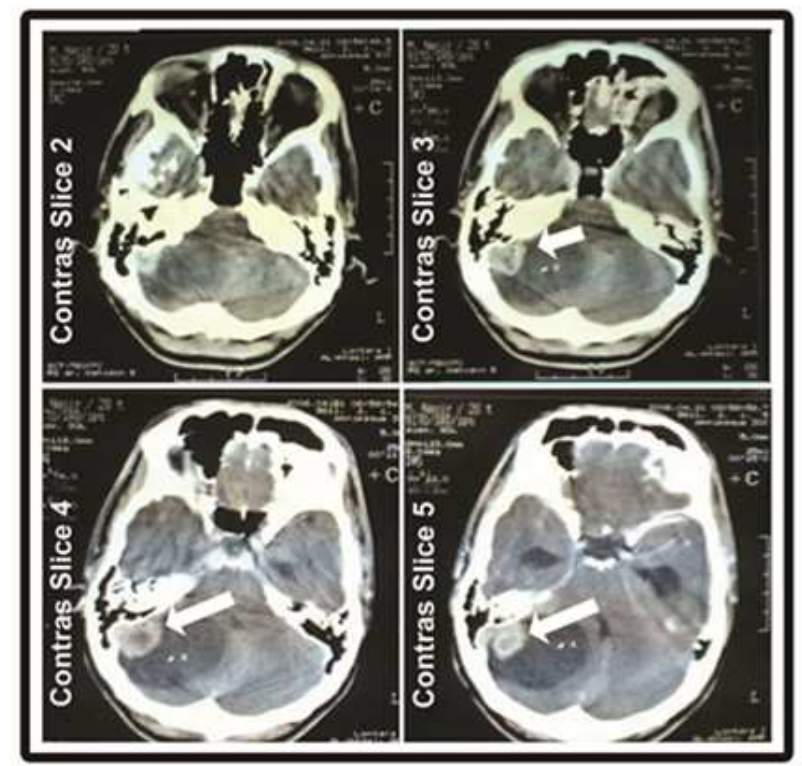

Figure 2. An axial head CT-scan with contrast shows a cystic mass on the wall with the solid component (white arrows) in the right posterior fossa (with the intensity range from 64.0 to $74.0 \mathrm{HU}$ ). Solid component becomes hyper-dense after contrast administration. Fourth ventricle seems driven to the left with dilatation of the lateral and third ventricles. Cerebellar midline shift to the left. Paranasal sinuses and mastoid air cell within normal limit and bones were intact.

\section{Discussion}

Von Hippel-Lindau (VHL) gene mutation, which is located on chromosome 3 p25-26, has a pivotal role in the occurrence of hemangioblastoma. Moreover, the highest protein expressions of VHL mRNA is located in Purkinje cells, Golgi type II, dentate nucleus of the cerebellum, the nuclei of Pontin and olivaria inferior nucleus medulla oblongata in patients with haemangioblastoma. VHL gene was also found in the renal tubular system; exocrine pancreas gland, adrenal cortex, and liver parenchyma [9, $10]$. 
This tumor is one of the rarest tumours of the CNS which accounts for about $2 \%$ of the entire CNS tumor and about $7.5 \%$ of all and $5 \%$ in spinal [11]. Haemangiblastoma was usually associated with VHL disease. The diagnosis of VHL-associated haemangiblastoma can be classified as follows [12]:

1. A patient with a VHL family history and one of this diagnosis: retinal haemangiblastoma, cerebellar haemangiblastoma, renal cell carcinoma or pheochromocytoma and multiple pancreatic cysts.

2. A patient without a VHL family history but in the presence of two or more diagnosis as previously mentioned.

In this case report, we showed a case with a robust allegation of von Hippel-Lindau (VHL) associated haemangioblastoma in the central nervous system (CNS). This diagnosis based on the findings: from the patient anamnesis, the patient complained about his blurred eyes, physical examination including neurological examination, we found the patient have high blood pressure 170/120 $\mathrm{mmHg}$ which maybe related with pheochromocytoma disease and from the funduscopic results; we observed papilla edema, which suspected with retinal edema. Moreover, CT-Scan of the head revealed a final result of cerebellar haemangioblastoma dextra with non-communicating hydrocephalus. After the excision of the tumor, histopathology findings suggested an angioma cavernous result. Of the above list, we have a strong suggestion that the diagnosis of the patient was a VHL-associated haemangioblastoma cerebellum in the central nervous system. There are two forms of this tumor: the solid and cystic forms. Macroscopic appearance of CNS haemangiblastoma: (1) simple cysts, $5 \%$; (2) macrocystic tumor with a dense red-coloured mural nodule, $60 \%$; (3) solid tumor, $26 \%$ and (4) solid tumor with internal small cysts, 9\% [13].

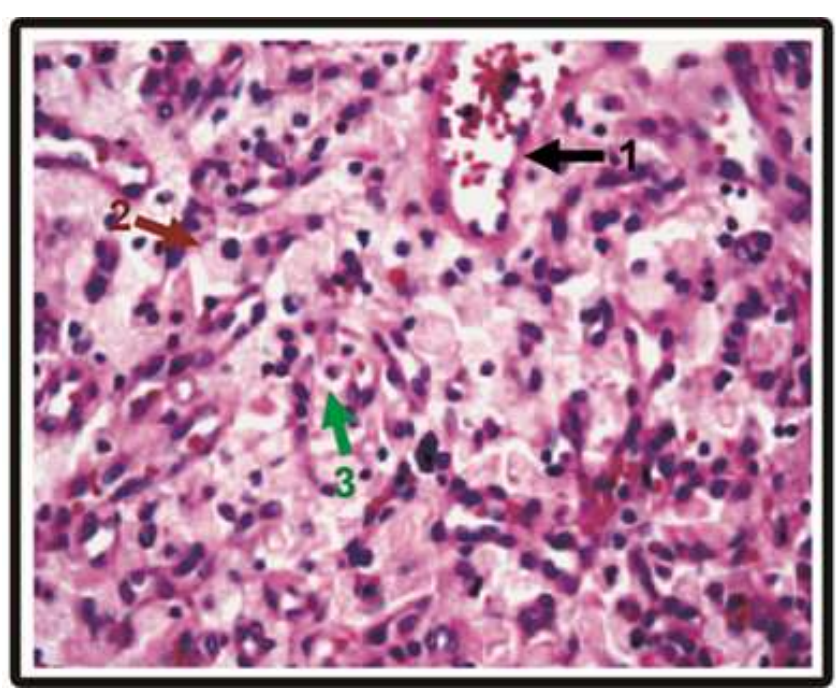

Figure 3. Cerebellum haemangioblastoma histopathology with the microscopically revealed tumor tissue with vascular proliferation, which containing erythrocytes-coated endothelial cells (Hematoxylin and eosin H.E. staining, 400x [1] Capillary endothelial cells containing red cells; [2] Vacuolated stromal cells or 'clear cell" and [3] Giant cell).
Cerebellum haemangioblastoma would cause typically symptoms like headache, papilla edema, dysmetria, intention tremor, and gait ataxia. When the tumor enlarges and presses the fourth ventricle, it will cause hydrocephalus resulting in cerebellar tonsillar herniation and worsening the level of consciousness until the death. Sometimes the tumor nodules can bleed; thus the clinical symptoms appear like a bleeding stroke $[3,14,15]$. The best treatment for this tumor is the management of surgery in the form of a complete tumor excision with sub occipital craniotomy approach $[1,3$, 14, 15, 16].

Patients with haemangioblastoma who do not get surgical treatment have a poor prognosis because the tumor will get bigger in time [17]. The outcome after surgery is good, amounting to $50-80 \%$ of patients can return to functional activities such as prior experience pain $[14,15,17]$ and still have a life expectancy of 5 to 20 years after surgery [14].

\section{Conclusion}

To diagnose a VHL-associated cerebellum haemangioblastoma in the CNS, comprehensive history taking (patient's anamnesis), physical and neurological examinations are very important. Radiological imaging by means of a CT scan especially contrasts CT scan, and an MRI is quite typical to support the diagnosis of this tumor. Furthermore, histopathological examination should be used to confirm the diagnosis after the tumor had been resection. Moreover, improved patient outcome requires total tumor resection.

\section{Conflict of Interest}

The authors declare no conflict of interest.

\section{References}

[1] James TJ, Yung WKA. Hemangioblastoma. In : Goetz CG ed. Text book of clinical neurology. 2nd ed. Philadelphia : Saunders, 2003; 1037.

[2] Dahret W. Hemangioblastoma of CNS. In : Grayson TH, ed. Radiology review manual. 2nd ed. Baltimore : Williams \& Wilkins, 1993: 180-1.

[3] Gilroy J. Hemangioblastoma. In : Basic neurology. 3rd ed. New York : McGraw-Hill, 2000: 416-7.

[4] Lindau A. Studien über Kleinhirnzysten. Bau, Pathogenese und Beziehungen zur Angiomatosis retinae. Acta Pathol Microbiol Scand 1926; S1: 1-128.

[5] von Hippel E. Ueber eine sehr seltene Erkrankung der Netzhaut. Klinische Beobachtungen. A von Graefe's Arch Ophthalmol 1904; 59: 83-106.

[6] Vates GE, Auguste KI, Berger MS. Hemangioblastomas. In : Berger MS, Prades MD, eds. Textbook of neuro-oncology. 1st ed. Philadelphia : Elsevier Saunders, 2005: 294-300 
[7] Solomon RA, Spellman JP, Mohr JP. Hemangioblastoma. In : Rowland LP, ed. Merritt's neurology. 10th ed. Philadelphia : Lippincott Williams \& Wilkins, 2000; 374-5

[8] Neumann HPH, Eggert HR, Weigel K, et al. Hemangioblastomas of the central nervous system. A 10 year study with special reference to von Hippel-Lindau syndrome. J Neurosurg 1989; 70:24-30.

[9] Bohling T, Plate KH, Haltia M, et al: von Hippel-Lindau disease and capillary haemangioblastoma. In Cavanee WK (ed): World Health Organization Classification of Tumours: Pathology and Genetics of Tumors of the Nervous System. Lyon, France, IARC Press, 2000.

[10] Frantzen C, Links TP, Giles RH. Von Hippel-Lindau Disease. 2000 May 17 [Updated 2012 Jun 21]. In: Pagon RA, Bird TD, Dolan CR, et al., editors. GeneReviews ${ }^{\mathrm{TM}}$ [Internet]. Seattle (WA): University of Washington, Seattle;1993-.Available from: http://www.ncbi.nlm.nih.gov/books/NBK1463/

[11] Resche F, Moisan JP, Mantoura J, de Kersaint-Gilly A, Andre MJ, Perrin-Resche I et al. Haemangioblastoma, haemangioblastomatosis, and von Hippel-Lindau disease. Adv Tech Stand Neurosurg 1993; 20:197- 304: 197-304.
[12] Friedrich CA. Von Hippel-Lindau syndrome. A pleomorphic condition. Cancer 1999; 86(11 Suppl):2478-2482.

[13] Richard S, Campello C, Taillandier L, Parker F, Resche F. Haemangioblastoma of the central nervous system in von Hippel-Lindau disease. French VHL Study Group. J Intern Med 1998; 243(6):547-553.

[14] Solomon RA, Spellman JP, Mohr JP. Hemangioblastoma. In : Rowland LP, ed. Merritt's neurology. 10th ed. Philadelphia : Lippincott Williams \& Wilkins, 2000; 374-5.

[15] Victor M, Ropper AH. Hemangioblastoma of the cerebellum. In : Adams and Victor's principles of neurology. 7th ed. New York : McGraw-Hill, 2001; 705-6.

[16] Vates GE, Auguste KI, Berger MS. Hemangioblastomas. In : Berger MS, Prades MD, eds. Textbook of neuro-oncology. 1st ed. Philadelphia: Elsevier Saunders, 2005: 294-300.

[17] Haughton VM, Daniels DL. Hemangioblastoma. In: William AL, Haughton VM, eds. Cranial computed tomography. ST Louis: The CV Mosby Company, 1985: 382-6. 